\title{
ANALISA PERBEDAAN LPS (LAST PLANNER SYSTEM) DENGAN SISTEM KONVENSIONAL SERTA PENGARUH CPM DAN BAR CHART PADA LPS
}

\author{
Sadhu Adwitya (1,*) $^{\text {, M. Agung Wibowo'), Syafrudin }}{ }^{\text {2) }}$ \\ ${ }^{1)}$ Departemen Teknik Sipil, Fakultas Teknik, Universitas Diponegoro \\ Jl. Prof. Soedarto, Tembalang, Semarang 50275 \\ ${ }^{2)}$ Departemen Teknik Lingkungan, Fakultas Teknik, Universitas Diponegoro \\ Jl. Prof. Soedarto, Tembalang, Semarang 50275 \\ ${ }^{*}$ E-mail: sadhuadwityaa@gmail.com
}

\begin{abstract}
Two generally method / tools which used in project construction management system in Indonesia and the name are CPM (critical part method) or network planning and Bar Chart. The system used general method called conventional management system. Nowadays, was appeared one of a new system which seldom to applied in Indonesia, it is called LPS (last planner system). This research, researcher doing analyzed the differences between LPS and conventional management system. The result which obtained in this research are LPS dominated to accentuates team collaborative in the scheduling planning, resource allocation, control and enhance of work productivity, issue solved, regularly scheduling planning. Conventional management system more rely on the way CPM and Bar Chart working in that system with project manager decision. Planning of the schedule in this system doing by scheduling team. rescheduling in this system is not routine, it's depend by construction progress. CPM and Bar Chart methods is influence on LPS. The both of methods was appeared in master scheduling, look a head scheduling, weekly work planning, shielding production, workable back log, percent plan completed and reliable promise process
\end{abstract}

Kata kunci : Bar Chart, CPM (critical path method), Last Panner System

\section{PENDAHULUAN}

Fasilitas fisik yang dikembangkan atau dibutuhkan oleh para agen publik untuk fungsi-fungsi pemerintahan dalam hal penyediaan air, tenaga listrik, pembuangan limbah, transportasi dan pelayanan-pelayanan similar untuk memfasilitasi tujuantujuan ekonomi dan sosial merupakan pengertian infrastruktur (Ramadhani, 2017).

Pembangunan infrastruktur adalah salah satu aspek penting dan vital dalam mempercepat proses pembangunan nasional. Adanya infrastruktur memberikan peranan penting, yaitu sebagai salah satu bagian dari roda penggerak pertumbuhan ekonomi Indonesia. Hal tersebut mengingatkan kita bahwa laju pertumbuhan ekonomi disuatu negara tidak dapat dipisahkan dari ketersediaanya infrastruktur di negara tersebut (Direktorat Riset dan Pengabdian Masyarakat Universitas Indonesia, 2007). Oleh karena itu, 
pembangunan di sektor ini (infrastruktur) menjadi fondasi dari pembangunan ekonomi.

Agar tercapai tujuan pembangunan infrastruktur yang baik, pihak pengembang ataupun pemilik proyek konstruksi harus mempunyai schedule pelaksanaan atau penjadwalan waktu pelaksanaan proyek yang mampu mengontrol jalanya pelaksanaan proyek itu sendiri. Umumnya kedua pihak tersebut menggunakan satu metode penjadwalan dalam satu pelaksanaan proyek konstruksi dan metode penjadwalan yang sering digunakan adalah Network planning yaitu CPM (Critical Path Method) dan metode Bar Chart. Menurut Ariyanto, (2010) dan Febri, et al. (2013), Penggunaan Bar Chart umum digunakan dalam scheduling pelaksanaan karenamudah dipahami sedangkan Metode jaringan kerja (CPM) memiliki keandalan dalam menunjukkan secara spesifik hubungan logika ketergantungan antar kegiatan dan menentukan lintasan kritis kegiatan proyek sehingga kegiatan yang menjadi prioritas apabila terjadi keterlambatan dapat diketahui.

Pada Era modern seperti saat ini, banyak penelitian yang meneliti tentang cara penangulangan permasalahan pada kegiatan konstruksi. Lean Construction adalah suatu metode yang digunakan pada pekerjaan konstruksi dengan cara meminimalkan waste berupa material dan waktu, dengan tujuan untuk meningkatkan value (nilai) (Mudzakir, et al. 2017). Pada awalnya Lean Construction merupakan teknik dalam industi manufacturing yang oleh Taichii Ohno di tahun 1950 dikembangkan di Sektor Konstruksi. Salah satu tolls yang terdapat dalam Lean Construction adalah last planner system (LPS).

Selain Itu, (Ballard, 2000) juga mengembangkan sistem dalam manajemen proyek yang dapat menutupi celah yang ada pada sistem manajemen konvensional. Sistem tersebut dinamakan Last Planner System. Last Planner System merupakan sistem manajemen proyek yang mengontrol produksi dalam hal schedule pelaksanaan atau penjadwalan waktu pelaksanaan proyek, sehingga dapat meningkatkan keterkaitaan antara pekerjaan, kinerja serta produktifitas suatu proyek konstruksi (Human and Zuldi, 2018).

Dilain sisi Ballard, (2000) mengemukakan bahwa suatu hal yang menyebkan tidak efektif dari teknik tradisonal yaitu kontrol aliran baru dapat dilakukan setelah suatu kejadian atau peristiwa muncul. Last Planner System merupakan teknik dapat digunakan dalam perencanaandan kontrol konstruksi, dengan mengfokuskan kepada orang-orang yang membuat keputusan di lokasi. Last Planner System ini berkomitmen untuk menetapkan rencana induk tugas pada awal sesi dengan menggunakan metode Pull Planning (Pellicer, et al. 2015). Penggunaan schedule pelaksanaan atau penjadwalan waktu pelaksanaan proyek Pull Planning dalam proyek konstruksi, berpotensi menghilangkan kendala pada rencana diminggu berikutnya dan 
meningkatkan aliran produksi pada proyek tersebut. Pertemuan mingguan digunakan untuk membahas peninjauan tugas yang dilakukan pada minggu sebelumnya untuk mengidentifikasi masalah dan mengusulkan solusi (Pellicer, et al. 2015).

Hal tersebut menimbulkan rasa keingintahuan tentang perbedaan diantara metode manajemen proyek konstruksi konvesional (menggunakan network planning, (Critical Path Method) dan atau Bar Chart) dengan metode proyek konstruksi menggunakan last planner system. Keingin tahuan tersebut muncul karena pada umumnya proyek konstruksi saat ini menggunakan metode CPM (Critical Path Method) dan Bar Chart dalam pelaksanaanya. Unutk saat ini masih jarang ditemui suatu proyek konstruksi yang menggunakan sistem manajemen last planner system dengan pull planning sebagai metode penjadwalannya di Indonesia. Hal tersebut dikarenaka last planner system merupakan sistem manajemen baru dalam proyek konstruksi sedangkan Bar Chart dan CPM sudah dikenal dan digunakan lama sebagai metode penjadwalan dalam proyek konstruksi (sistem manajemen proyek konvensional).

Maksud dari penelitian ini adalah untuk membandingkan sistem manajemen proyek last planner system dengan sistem manajemen proyek yang menggunakan network planning (Critical Path Method) dan atau Bar Chart dengan cara mensimulasikannya pada suatu proyek konstruksi yang sama, yaitu Proyek Rehabilitasi Saluran Induk dan Sekunder Klambu Kiri. Adapun dalam penelitian ini bertujuan untuk mencari perbedaan proyek dengan sistem manajemen konvensional dengan proyek yang menggunakan last planner system, serta mencari tahu pengaruh CPM dan Bar Chart pada Last planner system dengan bantuan dari Proyek Rehabilitasi Saluran Induk dan Sekunder Klambu Kiri yang terletak Di Desa Klambu, Kecamatan Klambu, Kabupaten Grobogan, Provinsi Jawa Tengah dan berakhir di Desa Wedung, Kabupaten Demak, Provinsi Jawa Tengah.

Didalam mengidentifikasi faktor mana saja yang termasuk dalam ruang lingkup masalah penelitian dan faktor mana saja yang tidak termasuk dalam ruang lingkup masalah penelitian maka diperlukan penetapan batasan masalah dalam penelitian. Terdapat tiga ruanglingkup yang digunakan dalam penelitian ini, yaitu Penelitian ini menggunakan sudut pandang pelaksana atau kontraktor, data yang digunakan dalam penelitian merupakan data yang dimabil Proyek Rehabilitasi Saluran Induk dan Sekunder Klambu Kiri. dan hanya pada pekerjaan saluran BKKi.1 BKKi. 15 dan perbandingan hanya pada manajemen proyek konstruksi konvnsional (network planning CPM dan Bar Chart) dengan last planner system pada tahapan penjadwalan proyek.

Penelitian ini bermanfaat untuk memberikan edukasi, pemahaman dan pengetahuan tentang perbedaan antara 
sistem manajemen proyek konstruksi yang menggunakan last planner system dan sistem manajemen konstruksi konvensional (network planning CPM dan Bar Chart). Dan mengetahui letak, bentuk dan kegunaan CPM dan Bar Chart pada last planner system.

\section{METODE PENELITIAN}

Penelitian ini dilakukan menggunakan data dari Proyek Rehabilitasi Saluran Induk Dan Sekunder Klambu Kiri. Proyek tersebut terletak di Provinsi
Jawa Tengah, tepatnya berawal di Kecamatan Klambu, Godong, Kabupaten Grobogan dan berakhir di Kecamatan Karanganyar, Gajah, Mijen, Demak, Wedung Kabupaten Demak. Diagram alir analisis data yang digunakan sebagai acuan dalam pelaksanaan penelitian. Kerangka pemikiran yang baik yaitu dapat menjelaskan apa runtutan garis besar yang akan diteliti. Untuk lebih jelasnya dapat dilihat pada Gambar 1.

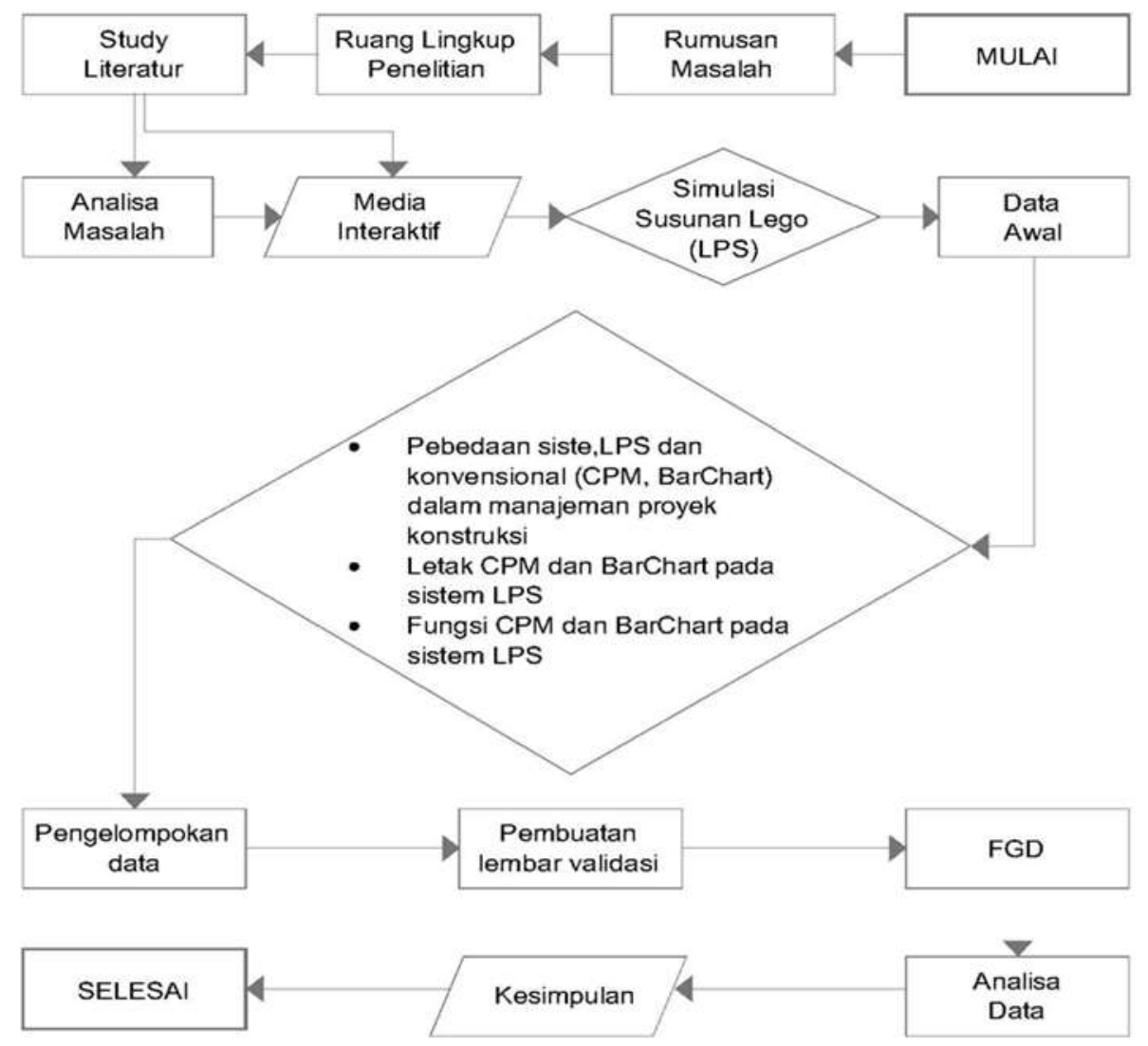

Gambar 1. Diagram Alir Penelitian

Penelitian ini digolongkan deskriptif komparatif, deskriptif dalam dalam penelitian jenis deskriptif mendeskripsikan atau memaparkan komparatif (comparative descriptive masalah yang ada berdasarkan data research). Penelitan berbentuk yang digunakan sedangkan komparatif 
berarti membandingkan (Ariyanto, didapat dari Proyek Rehabilitasi 2010). Teknik analisa komparasi Saluran Induk Dan Sekunder Klambu dipergunakan untuk mengetahui Kiri dan data yang dipergunakan perbedaan yang muncul antar variabel. hanyalah data pada sub-pekerjaan Cara yang digunakan dalam teknik ini saluran, BKKi.1 - BKKi. 15 (Gambar yaitu dengan membandingkan dua atau 2). Data penjadwalan proyek (Gambar lebih data yang akan diteliti. 2) dan gambar kerja (Gambar 3), (Siswanto, et al. 2017). Adapun selanjutnya digunakan untuk diolah tahapan dalam penelitian ini yaitu: menjadi bentuk simulasi proyek a. Perancangan susunan dan peraturan pembangunan saluran menggunakan lego untuk simulasi last planner susunan lego sebagai material system.

Pembuatan media simulasi proyek menggunakan data yang

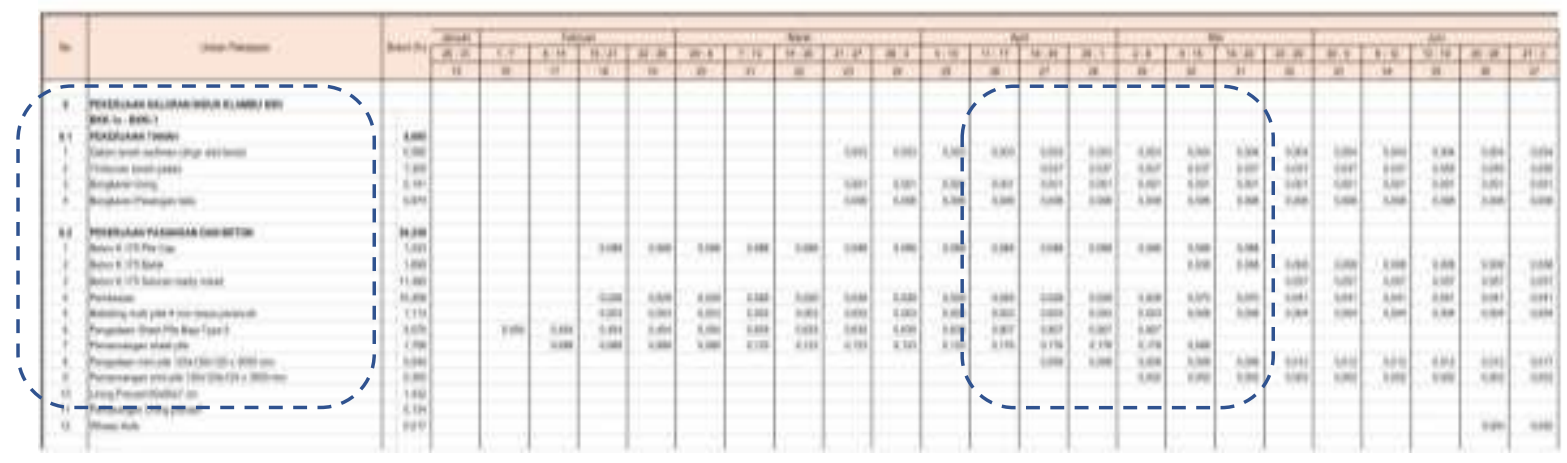

Gambar 2. Detail Proyek Rehabilitasi Saluran Induk Dan Sekunder Klambu Kiri, BKKi.1 - BKKi. 15. (sumber : PT. WIJAYA KARYA Tbk.)

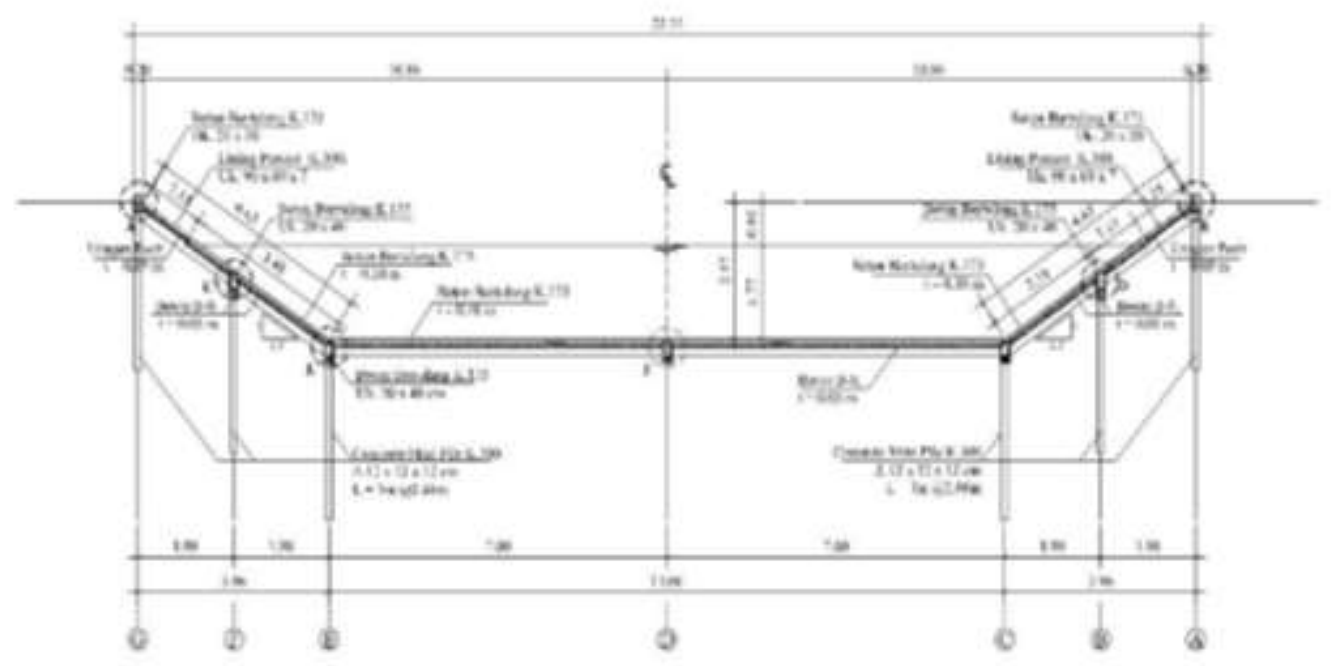

Gambar 3. Potongan Proyek Rehabilitasi Saluran Induk Dan Sekunder Klambu Kiri, BKKi.1 - BKKi. 15. (sumber : PT. WIJAYA KARYA Tbk.) 
Gambar 4 merupakan visualisasi tiga dimensi dari bentuk susunan lego berserta penjadwalannya yang akan dipergunakan dalam proses simulasi. Simulasi tersebut diperguinakan untuk memahamnkan simulator mengenai cara kerja LPS. Warna lego dalam penyusunan bentuk ini sudah disesuaikan dengan pengelompokan item pekerjaan yang digunakan dan letak posisi item pekerjaan tersebut sesuai dengan gambar kerja dan Penjadwalan (Gambar 2 \& 3) yang digunakan di lapangan.

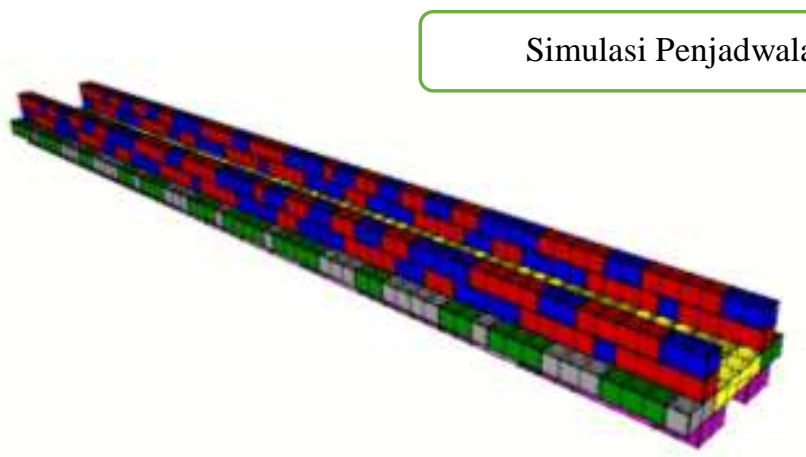

\begin{tabular}{|c|c|c|c|c|c|c|c|c|c|c|c|c|c|}
\hline \multirow{2}{*}{$\begin{array}{c}\text { Item } \\
\text { Pekerjan }\end{array}$} & \multirow{2}{*}{ Volume } & \multirow{2}{*}{ Satuan } & \multicolumn{4}{|c|}{ Bulan 1} & \multicolumn{4}{|c|}{ Bulan 2} & \multicolumn{3}{|c|}{ Bulan 3} \\
\hline & & & 1 & 2 & 3 & 4 & 5 & 6 & 7 & 8 & 9 & 10 & 11 \\
\hline Hitam & 50 & pcs & & & & & & & & & & & \\
\hline Kuning & 45 & pcs & & & & & & & & & & & \\
\hline Hijau & 25 & pcs & & & & & & & & & & & \\
\hline Abu-abu & 24 & pcs & & & & & & & & & & & \\
\hline Biru & 44 & pcs & & & & & & & & & & & \\
\hline Merah & 44 & pcs & & & & & & & & & & & \\
\hline
\end{tabular}

Gambar 4. Bentuk Susunan Lego untuk simulasi LPS

b. Tahapan simulasi last planner sustem menggunakan alat bantu lego

Tahapan simulasi mengacu pada last planner production system yang sudah diteliti oleh Ballard, et al (2007). Adanya tahapan simulasi susunan lego berguna untuk memberikan pemahaman kepada simulator tetntang last planner system sehingga simulator dapat memahami, mengetahui dan membayangkan last planner system ketika diimplementasikan pada proyek konstruksi dan dapat membandingkan dengan manajemen proyek konvensional (network planning (CPM) dan atau Bar Chart). Adapun tahapan simulasi last planner system.

c. Mengajukan pertanyaan pasca simulasi kepada simulator.

Didalam pencarian data awal, peneliti harus membuat pertanyaan untuk memperoleh data yang dibutuhkan dalam penelitian. Pertanyaan ini digunakan untuk mencari data awal tentang perbedaan antara manajemen proyek LPS dengan manajemen proyek konvensional (CPM (network planning) dan Bar Chart) kepada simulator. Adapun data 
tersebut akan dipergunakan untuk bahan diskusi dan validasi ditahap FGD (Focuss Grup Discussion).

\section{d. Focuss Grup Discussion (FGD)} dan Validasi data oleh partisipan.

Tahapan ini merupakan tahapan lanjutan yang dilaksanakan setelah para simulator selesai mensimulasikan media interaktif dan menjawab pertanyaan yang diberikan oleh peneliti. Focuss Grup Discussion (FGD) menjadi sarana diskusi dan validasi hasil pertanyaan dan pengamatan pasca simulasi. Data hasil validasi akan digunakan sebagai bahan analisis peneliti.

Teknik pengolahan data dalam penelitian ini menggunakan penolahan data kuantitatif. Terdapat tiga tahapan pengolahan data, yaitu dengan cara, pengelompokan data berdasarkan PDCA (plan-do-check-act), reduksi, penyajian dan menarik kesimpulan atau verifikasi.

\section{HASIL DAN PEMBAHASAN}

Tabel 1. Peserta Simulasi dan FGD

\begin{tabular}{|l|l|l|l|}
\hline No & \multicolumn{1}{|c|}{ Jabatan } & \multicolumn{1}{|c|}{ Instansi / perusahaan } & Pengalaman \\
\hline 1 & Dekan Teknik & FAKULTAS TEKNIK UNIVERSITAS DIPONEGORO & \\
\hline 2 & Tenaga Ahli & PT. NAUVAL PERKASA & 3,5 tahun \\
\hline 3 & $\begin{array}{l}\text { Kepala Manajemen } \\
\text { Konstruksi }\end{array}$ & PT. MAKSI SOLUSI ENJINER & 7,5 tahun \\
\hline 4 & Tim Supervisi & PT. TRI PATRA KONSULTAN & 4 tahun \\
\hline 5 & $\begin{array}{l}\text { Pelaksana Utama, } \\
\text { Kepala enjinering }\end{array}$ & PT. WIJAYA KARYA Tbk & 7,5 tahun \\
\hline 6 & Arsitek & CV. GALIH LOKA & 4 Tahun \\
\hline 7 & Tim Supervisi & CV. TITIS ENGINEERING & 3 Tahun \\
\hline 8 & Tim Perencana & PT. KARSA HARYA MULYA & 4 tahun \\
\hline
\end{tabular}

Konsep plan plan-do-check-act digunakan untuk mempermudah dalam pemilihan dan pengelompokan data
Terdapat dua macam data dan pembahasan pada penelitian ini. Yaitu, Perbedaan sistem manajemen proyek konstruksi LPS dengan Konvensional (CPM (network planning) - Bar Chart) dan Fungsi CPM (Network Planning) Bar Chart Pada Tahapan LPS.

\section{Data Perbedaan sistem manajemen proyek konstruksi LPS dengan Konvensional (CPM (network planning) - Bar Chart)}

Pembahasan perbedaan sistem manajemen proyek LPS dan konvensional dilakukan setelah mendapat data dari tahap simulasi last planner system menggunakan media lego dan melakukan tahap FGD bersama tenaga ahli. Data masukan yang diberikan oleh tenaga ahli difase FGD menjadi bahan untuk peneliti menganalisa perbedaan kedua sistem manajemen proyek yang diteliti. Adapun peserta simulasi dan FGD dapat dilihat pada Tabel 1 . 
Tabel 2. Data Perbedaan sistem manajemen proyek konstruksi LPS dan Konvensional (CPM (network planning) dan Bar Chart)

\begin{tabular}{|c|c|c|c|c|c|}
\hline \multirow[b]{2}{*}{ No } & \multirow{2}{*}{$\begin{array}{l}\text { PDCA } \\
\text { (Plan- } \\
\text { Do- } \\
\text { Check- } \\
\text { Act })\end{array}$} & \multicolumn{2}{|c|}{ Lembar Validasi Pernyataan (Data Awal) } & \multicolumn{2}{|c|}{ Masukan FGD } \\
\hline & & $\begin{array}{c}\text { Sistem Konvensional } \\
\text { (menggunakan CPM (network } \\
\text { planning) dan Bar Chart) }\end{array}$ & Last Planner System & $\begin{array}{c}\text { Sistem Konvensional } \\
\text { (menggunakan CPM (network } \\
\text { planning) dan Bar Chart) }\end{array}$ & Last Planner System \\
\hline \multirow[t]{3}{*}{1} & \multirow[t]{3}{*}{ Plan } & $\begin{array}{l}\text { - Umumnya jadwal proyek (CPM } \\
\text { dan Bar Chart) dibuat dan } \\
\text { ditetapkan oleh PM (project } \\
\text { manager)dan Tim penjadwalan } \\
\text { proyek diawal proyek. } \\
\text { - Pembuatan penjadwalan ketika } \\
\text { proyek berlangsung bersifat } \\
\text { kondisional (tidak rutin), } \\
\text { bergantung pada progress } \\
\text { pengerjaan ketika muncul berubah } \\
\text { desain, keterlambatan, perubahan } \\
\text { volume, isu besar }\end{array}$ & $\begin{array}{ll} & \text { Jadwal proyek dibuat diawal dengan } \\
\text { kontribusi dari seluruh anggota tim dan } \\
\text { supplier, serta partisipasi dari tim } \\
\text { supervisi dan perwakilan owner. } \\
\text { Melakukan simulasi terhadap urutan } \\
\text { kegiatan serta ketersediaan sumber daya } \\
\text { pada penjadwalan yang sudah dibuat }\end{array}$ & $\begin{array}{l}\text { CPM (network planning), Bar Chart } \\
\text { - Jadwal Bar Chart dibuat dari awal } \\
\text { sampai akhir, kemudian dapat di } \\
\text { reschedule ketika sudah } \\
\text { melaksanakan MC (mutual check) }\end{array}$ & $\begin{array}{l}\text { - Pada planning, supplier, } \\
\text { supervisi dan owner tidak } \\
\text { ikut membuat } \\
\text { pemjadwalan, tapi hanya } \\
\text { memberikan informasi, } \\
\text { karena planning tetap } \\
\text { menjadi tanggung jawab } \\
\text { kontraktor. } \\
\text { - Pembuatan penjadwalan } \\
\text { bersifat rutin, tidak } \\
\text { bergantung pada } \\
\text { progress. }\end{array}$ \\
\hline & & $\begin{array}{l}\text { Dalam perencanaannya penjadwalan, } \\
\text { - Bar Chart menggunakan susunan } \\
\text { balok yang berfungsi memberi } \\
\text { gambaran waktu dan urutan } \\
\text { pekerjaan } \\
\text { - Pada CPM durasi pekerjaan } \\
\text { dihitung menggunakan Activity on } \\
\text { Arrow (AOA) untuk mendapatkan, } \\
\text { total float (TF), free float (FF) dan } \\
\text { Independent float (IF). }\end{array}$ & $\begin{array}{l}\text { Dalam merencanakan penjadwalan LPS, } \\
\text { menggunakan : } \\
\text { - teknik pulling } \\
\text { - kolaboratif kontraktor, supplier dan } \\
\text { perencana } \\
\text { - konsep plan-do-check-act } \\
\text { Untuk merancang Look ahead planning, } \\
\text { wekly work planning dan daily work } \\
\text { planning }\end{array}$ & $\begin{array}{l}\text { - CPM tidak menggunakan AOA } \\
\text { untuk menghitung durasi } \\
\text { pekerjaan }\end{array}$ & $\begin{array}{l}\text { Kolaboratif kontraktor, } \\
\text { supplier, perencana dan } \\
\text { owner, karena owner } \\
\text { yang mempunyai } \\
\text { milestone. } \\
\text { Supplier dan perencana } \\
\text { tidak ikut merencanakan } \\
\text { penjadwalan. }\end{array}$ \\
\hline & & $\begin{array}{l}\text { Pada CPM dan Bar Chart rencana } \\
\text { penjadwalan hanya dibuat dalam skala } \\
\text { waktu mingguan dan bulanan. }\end{array}$ & $\begin{array}{l}\text { Pada LPS terdapat rencana penjadwalan } \\
\text { bulanan (six week scheduling), mingguan } \\
\text { (weekly work planning) dan harian (daily } \\
\text { work planning) dibuat detai dengan } \\
\text { mengandalkan: } \\
\text { a. Look a head log (control waktu mingguan }\end{array}$ & $\begin{array}{l}\text { CPM (network planning), Bar Chart } \\
\text { - } \quad \text { Penjadwalan dapat dibreakdown } \\
\text { ke bentuk harian. } \\
\text { - } \quad \text { Pekerjaan dapat dibuat dalam } \\
\text { berbagai skala, hari, jam, minggu. }\end{array}$ & - \\
\hline
\end{tabular}




\begin{tabular}{|c|c|c|c|c|c|}
\hline \multirow{3}{*}{ No } & \multirow{3}{*}{$\begin{array}{c}\text { PDCA } \\
\text { (Plan- } \\
\text { Do- } \\
\text { Check- } \\
\text { Act })\end{array}$} & \multicolumn{2}{|c|}{ Lembar Validasi Pernyataan (Data Awal) } & \multicolumn{2}{|c|}{ Masukan FGD } \\
\hline & & $\begin{array}{c}\text { Sistem Konvensional } \\
\text { (menggunakan CPM (network } \\
\text { planning) dan Bar Chart) }\end{array}$ & Last Planner System & $\begin{array}{c}\text { Sistem Konvensional } \\
\text { (menggunakan CPM (network } \\
\text { planning) dan Bar Chart) }\end{array}$ & Last Planner System \\
\hline & & & $\begin{array}{l}\text { dan bulanan) } \\
\text { b. Constraint log dan balancing process } \\
\text { (control sumber daya) } \\
\text { c. First runs studies (control metode kerja) } \\
\text { d. Shielding production (control aliran } \\
\text { pekerjaan, sebagai penyaring resource } \\
\text { e. Workable back log (control hambatan } \\
\text { pekerjaan yang akan dilakukan) } \\
\text { f. Reliable promise (control kemunculan } \\
\text { issue dan penyelesaiannya) } \\
\text { g. Performance evaluation (evaluasi } \\
\text { pengerjaan) }\end{array}$ & & \\
\hline 2 & Do & $\begin{array}{l}\text { Bar Chart dan CPM mengacu pada } \\
\text { durasi waktu dan bobot kurva sebagai } \\
\text { acuan pengerjaan proyek dengan } \\
\text { menggunakan : } \\
\text { a. Bar Chart } \\
\text { - Kurva S (durasi waktu } \\
\text { pengerjaan) dan Diagram } \\
\text { balok (target realisasi bobot) } \\
\text { b. CPM (control waktu) } \\
\text { - Total float (TF). } \\
\text { - Free float (FF). } \\
\text { - Independent float (IF). }\end{array}$ & $\begin{array}{l}\text { LPS mengacu pada peningkatan produktivitas } \\
\text { dalam pengerjaan proyek, dengan } \\
\text { menggunakan : } \\
\text { a. Look a head schedule (control waktu } \\
\text { mingguan dan bulanan) } \\
\text { b. Constraint analysis dan balancing } \\
\text { process (control sumber daya) } \\
\text { c. First runs studies (control metode } \\
\text { kerja) } \\
\text { d. Shielding production (control pekerjaan } \\
\text { yang siap dilaksanakan) } \\
\text { e. Workable back log (control waktu } \\
\text { f. Rarian) } \\
\text { issue dan penyelesaiannya) } \\
\text { g. Performance evaluation (evaluasi } \\
\text { pengerjaan) }\end{array}$ & $\begin{array}{l}\text { CPM (network planning), Bar Chart } \\
\text { a. CPM dan Bar Chart belum } \\
\text { mengarah pada produktivitas } \\
\text { b. Pada kurva S (target realisasi } \\
\text { bobot) dapat menjadi kontrol dari } \\
\text { sumber daya maupun untuk } \\
\text { mengevaluasi pengerjaan, } \\
\text { sehingga tetap pada pengingkatan } \\
\text { produktivitas. } \\
\text { c. CPM dan Bar Chart yang } \\
\text { berkaitan dengan kurva S bisa } \\
\text { dibuat WBS (work breakdown } \\
\text { structure) untuk kontrol } \\
\text { produktivitas } \\
\text { d. Teknik produktivitas, CPM dapat } \\
\text { digunakan dalam erened value } \\
\text { analysis, menganalisa BCWS, } \\
\text { BCW, dan ACWP. }\end{array}$ & $\begin{array}{l}\text { Penepatan janji yang sudah } \\
\text { diberikan }\end{array}$ \\
\hline
\end{tabular}




\begin{tabular}{|c|c|c|c|c|c|}
\hline \multirow{4}{*}{ No } & \multirow{4}{*}{$\begin{array}{l}\text { PDCA } \\
\text { (Plan- } \\
\text { Do- } \\
\text { Check- } \\
\text { Act })\end{array}$} & \multicolumn{2}{|c|}{ Lembar Validasi Pernyataan (Data Awal) } & \multicolumn{2}{|c|}{ Masukan FGD } \\
\hline & & $\begin{array}{c}\text { Sistem Konvensional } \\
\text { (menggunakan CPM (network } \\
\text { planning) dan Bar Chart) }\end{array}$ & \multirow{2}{*}{$\begin{array}{l}\text { Last Planner System } \\
\text { Sebelum konstruksi dimulai, terdapat tahapan } \\
\text { daily huddle (daily work planning) yaitu rapat } \\
\text { harian atau kumpul bersama tim dilapangan } \\
\text { untuk mengingatkan target dan kegiatan hari } \\
\text { ini. }\end{array}$} & \multirow{2}{*}{$\begin{array}{l}\text { Sistem Konvensional } \\
\text { (menggunakan CPM (network } \\
\text { planning) dan Bar Chart) } \\
\text { - } \quad \text { Rapat harian, daily huddle pada } \\
\text { LPS memiliki prosedur yang } \\
\text { sama dengan TBM (tools box } \\
\text { meating) } \\
\text { TBM (tools box meating) pada } \\
\text { Network planning dan Bar Chart } \\
\text { bersifat tidak formal }\end{array}$} & Last Planner System \\
\hline & & $\begin{array}{l}\text { Pada Network planning dan Bar } \\
\text { Chart, rapat harian sebelum } \\
\text { pelaksanaan bergantung pada } \\
\text { kebijakan perusahaan. (tools box } \\
\text { meeting). }\end{array}$ & & & $\begin{array}{l}\text { Dailly huddle pada LPS } \\
\text { merupakan bagian dari step } \\
\text { yang fokus kepada tim, PIC } \\
\text { pekerjaan dan mandor/subkon } \\
\text { yang terlibat. LPS juga } \\
\text { menggunakan TBM (tools } \\
\text { box meating) kepada para } \\
\text { pekerja di lapangan. }\end{array}$ \\
\hline & & $\begin{array}{l}\text { Dalam total system manajemen, Bar } \\
\text { Chart dan Network Plannig (CPM) } \\
\text { berguna untuk memberikan informasi } \\
\text { tentang rencana bobot harian dan } \\
\text { waktu penyelesaian item pekerjaan } \\
\text { pada proyek konstruksi. }\end{array}$ & $\begin{array}{l}\text { Dalam total system manajemen, LPS } \\
\text { terintegrasi antara; Penjadwalan, Metode, } \\
\text { Sumber daya. Sinergi antar berbagai pihak } \\
\text { dalam proses realisasi proyek }\end{array}$ & $\begin{array}{l}\text { CPM (network planning), Bar Chart, } \\
\text { terdapat penjadwalan sumber daya, WI } \\
\text { (work instruction), tidak terupdate/ } \\
\text { kurang update dan kadang jauh dari } \\
\text { realisasi. Metode kerja ada, tapi secara } \\
\text { umum }\end{array}$ & $\begin{array}{l}\text { Total sistem pada LPS } \\
\text { lebih terupdate. } \\
\text { - LPS juga terintegrasi } \\
\text { mengenai manajemen } \\
\text { resiko. }\end{array}$ \\
\hline \multirow[t]{2}{*}{3} & Check & $\begin{array}{l}\text { Issu yang muncul pada hari tersebut } \\
\text { akan dilaporkan ke PM dan diadakan } \\
\text { rapat (hasil berita acara) atau PM } \\
\text { memberi keputusan kepada pihak } \\
\text { yang bertanggung jawab secara } \\
\text { langsung. }\end{array}$ & $\begin{array}{l}\text { Terdapat table issue (raliable promise) yang } \\
\text { dipergunakan untuk mencantumkan informasi } \\
\text { berupa isue yang muncul, penganggunjawab, } \\
\text { tanggal penyelesaian issue dan status harian } \\
\text { (selalu berubah) }\end{array}$ & $\begin{array}{l}\text { Pembahasan issue dilakukan saat rapat } \\
\text { progres }\end{array}$ & $\begin{array}{l}\text { - Realisasi penanganan pada } \\
\text { tabel issue lebih cepat } \\
\text { ditanggapi dari pada } \\
\text { penggunaan berita acara. } \\
\text { - Issue lebih mendetail, per } \\
\text { pekerjaan, kondisi } \\
\text { pekerjaan, dan ter-update }\end{array}$ \\
\hline & & $\begin{array}{l}\text { Progress realisasi digambar dalam } \\
\text { bentuk kurva S pada Bar Chart. Kurva } \\
\text { biru untuk rencana dan merah untuk } \\
\text { realisasi. }\end{array}$ & $\begin{array}{l}\text { Laporan progress PPC dapat dibuat dalam } \\
\text { bentuk kurva harian, mingguan ataupun } \\
\text { bulanan. Berisikan garis rencana (biru) dan } \\
\text { realisasi (merah). }\end{array}$ & - & I \\
\hline 4 & Act & $\begin{array}{l}\text { Terdapat rapat evaluasi mingguan } \\
\text { membahas progres realisasi proyek } \\
\text { dan issue yang diharuskan untuk } \\
\text { dirapatkan. }\end{array}$ & $\begin{array}{l}\text { Terdapat evaluasi mingguan menggunakan } \\
\text { performance evaluation log untuk } \\
\text { mempelajari hasil produktivitas dari } \\
\text { penjadwalan, sumber daya dan metode yang } \\
\text { sudah diterapkan. }\end{array}$ & $\begin{array}{l}\text { Tetap membahas metode dan sumber } \\
\text { daya }\end{array}$ & $\begin{array}{l}\text { Rapat evaluasi mingguan } \\
\text { LPS lebih terstruktur }\end{array}$ \\
\hline
\end{tabular}




\begin{tabular}{|c|c|c|c|c|c|}
\hline \multirow{4}{*}{ No } & \multirow{4}{*}{$\begin{array}{c}\text { PDCA } \\
\text { (Plan- } \\
\text { Do- } \\
\text { Check- } \\
\text { Act) }\end{array}$} & \multicolumn{2}{|c|}{ Lembar Validasi Pernyataan (Data Awal) } & \multicolumn{2}{|c|}{ Masukan FGD } \\
\hline & & $\begin{array}{c}\text { Sistem Konvensional } \\
\text { (menggunakan CPM (network } \\
\text { planning) dan Bar Chart) }\end{array}$ & Last Planner System & $\begin{array}{c}\text { Sistem Konvensional } \\
\text { (menggunakan CPM (network } \\
\text { planning) dan Bar Chart) }\end{array}$ & Last Planner System \\
\hline & & $\begin{array}{l}\text { Ketika ada perubahan, desain berubah, } \\
\text { keterlambatan, perubahan volume, isu } \\
\text { besar (ex. Pembebasan lahan), CPM } \\
\text { dan Bar Chart perlu dibuat ulang. }\end{array}$ & $\begin{array}{l}\text { LPS memungkinkan mengatasi perubahan } \\
\text { jadwal karena LPS memiliki sarana untuk } \\
\text { menyesuaikan antara penjadwalan dengan } \\
\text { progress dilapangan. Hal ini dilakukan pada } \\
\text { a. Look a head planning } \\
\text { b. Weekly work planning } \\
\text { c. Daily work planning }\end{array}$ & - & $\begin{array}{l}\text { Review schedule dalam LPS } \\
\text { lebih dinamis dibandingkan } \\
\text { Bar Chart dan CPM }\end{array}$ \\
\hline & & $\begin{array}{l}\text { Koordinasi dalam Bar Chart dan CPM } \\
\text { lebih mengikuti keputusan atau arahan } \\
\text { PM dan atau penetapan tim } \\
\text { penjadwalan. }\end{array}$ & $\begin{array}{l}\text { LPS memiliki target volume dan waktu suatu } \\
\text { kegiatan untuk dilaksanakan, serta PIC } \\
\text { (person in charge) yang terlibat. }\end{array}$ & $\begin{array}{l}\text { Bar Chart dan CPM tidak melibatkan } \\
\text { seluruh stake holder dalam } \\
\text { menentukan target volume dan waktu. }\end{array}$ & LPS lebih terstruktur \\
\hline
\end{tabular}


Hasil Akhir Analisa Perbedaan sistem manajemen proyek konstruksi LPS dengan Konvensional (CPM (network planning) - Bar Chart) dengan penelitian yang sudah ada.

Dari hasil penelitian pada tahapan panning, waktu pembuatan penjadwalan sistem LPS dan konvensional sama, yaitu dibuat pada awal proyek. Namun, pada LPS penjadwalan dibuat dengan kontribusi dari seluruh tim dan dilakukan simulasi terhadap urutan kegiatan serta ketersediaan sumber daya pada penjadwalan yang dibuat secara rutin (sustainable scheduling). Hal tersebut dapat diartikan bahwa dalam pembuatan penjadwalan LPS selalu terupdate dengan mengunggulkan kolaboratif antar anggota tim dalam penyusunan dan alokasi sumber daya. Hasi ini sesusai dengan penelitian Pellicer, et al (2015) Last Planner System adalah teknik untuk perencanaan dan kontrol konstruksi, yang difokuskan pada orang-orang yang membuat keputusan di lokasi.

Pada penjadwalan konvensional, penjadwalan hanya dibuat dan oleh tim penjadwalan dan PM (project manager) saja, adapun pembuatan penjadwalan ketika proyek berlangsung bersifat kondisional atau tidak rutin, bergantung pada progress pengerjaan ketika bobot merosot atau jatuh, perubahan desain, perubahan volume, issue besar (seperti pembebasan lahan). Pembuatan penjadwalan di sini dapat diartikan dengan membuat ulang atau reschedule baik pada Bar Chart ataupun CPM. Hasil ini sesuai dengan penelitian Ballard, (2000) yaitu, penyebab tidak efektif dari teknik konvensional yaitu kontrol aliran baru dapat dilakukan setelah suatu kejadian atau peristiwa muncul. Statement tersebut dapat diartikan bahwan isu besar yang mengakibatkan adanya reschedule dalam proyek berdampak pada perancangan kontrol aliran baru.

Dalam

perancangan penjadwalan, selain kolaboratif antar tim, LPS juga melibatkan supplier dan perencana dalam penetapan sumber daya dan penjelas kejelasan desain, penggunaan teknik pulling, dan konsep plan-do-check-act untuk merancang Look ahead planning, weekly work planning, dan daily work planning. Adapun hal tersebut berguna untuk mengakomodasi tahapan; Look a head log (control waktu mingguan dan bulanan), Constraint log dan balancing process (control sumber daya), First runs studies (control metode kerja), Shielding production (control pekerjaan yang siap dilaksanakan), Workable back log (control waktu harian), Reliable promise (control kemunculan issue dan penyelesaiannya) dan Performance evaluation (evaluasi pengerjaan).

Sedangkan dalam perancangan sistem proyek konvensional lebih mengunggulkan keunggulan Bar Chart dengan susunan balok yang berfungsi memberikan gambaran waktu serta urutan kegiatan. Hasil ini sejalan dengan penelitian Ariyanto, (2010) dan Husen, (2011) bahwa penyajian Bar Chart bersifat visual, sederhana dan mudah untuk dimengerti, tetapi tidak dapat menunjukkan secara spesifik hubungan logika ketergantungan antar 
kegiatan dan lintasan kritis proyek, serta tidak dapat mendeteksi secara langsung kegiatan yang mengalami gangguan dalam penjadwalan proyek.

CPM dengan total float (TF), free float (FF) dan Independent float (IF) berguna sebagai kontrol waktu pengerjaan pekerjaan serta keterlibatan supplier dan perencana dalam penetapan sumber daya dan penjelas kejelasan desain. Hasil perbandingan antara manajemen proyek konvensional dan LPS sesuai dengan penelitian Ballard, (2000), bahwa dalam LPS lebih unggul segi realisasi keterlibatan antar anggota tim dibandingkan metode tradisional.

Tahapan doing atau Pelaksanaan sistem LPS mengacu pada pengingkatan produktivitas dan penetapan janji yang sudah diberikan dalam pengerjaan proyek, sedangkan sistem manajemen proyek konvensional lebih mengikuti acuan durasi waktu dan bobot kurva dalam pengerjaan proyek. hasil ini sesuai dengan penelitian Fernandez-Solis, et al. (2013) dalam hal peningkatan produktivitas dan kolaborasi secara menyeluruh. TBM (tools box meeting) dalam LPS terbagi menjadi dua tahapan, yaitu daily huddle pada tahap daily work planning yang berfokus kepada PIC (person in charge) dan diteruskan dengan TBM pada pekerja di lapangan. Pada sistem manajemen proyek konvensional, hanya ada TBM pada pekerja di lapangan saja dan bersifat tidak formal atau bergantung pada kebijakan perusahaan.

Tahap checking prihal kemunculan issue atau problem pada saat konstruksi berlangsung mempunyai cara penyelesaian yang berbeda pada kedua sistem manajemen kosntruksi. Pada LPS, issue yang muncul akan diletakan pada tahapan reliable promise, yaitu tahap pencantuman issue pada papan issue. Adapun yang ditulis berupa keterangan tentang issue yang muncul, penganggung jawab, tanggal penyelesaian dan status harian. Hasil ini sesuai dengan penelitian Heery, (2010) yaitu pada LPS memungkinkan semua orang untuk mempertimbangkan solusi serta membuat urutan penjadwalan solusi dengan jadwal realisasi proyek.

Sedangkan pada sistem manajemen konvensional, issue yang muncul akan dilaporkan ke PM dan akan dibahas saat rapat progress mingguan dan dibuat berita acara mengenai issue tersebut. Laporan proges PPC (percent plan completed) pada LPS dibuat dua tahapan, yaitu berupa progress harian berupa tren kurva per hari dan laporan progress kurva S pada Master schedule (Bar Chart penawaran). Kurva tren pada LPS dipergunakan untuk control produktivitas kerja harian dan sebagai tambahan informasi untuk update schedule. Pada sistem manajemen proyek konvensional, laporan PPC hanya ada pada Bar Chart berupa kurva $\mathrm{S}$ realisasi mingguan. Hasil ini jika digabungkan dengan hasil pada tahapan action di bawah sesuai dengan penelitian Ballard, et al (2007) bahwa keberhasilan rencana pada peramalan pekerjaan yang akan dicapai pada akhir minggu diukur alam bentuk PPC dan akar penyebab dari kegagalan rencana lalu diselidiki pada akhir tiap minggu 
sehingga mereka dapat dihindari di masa depan.

Action process atau tahapan evaluasi kerja pada LPS mengunaan keunggulan performance evaluation $\log , \quad \log$ tersebut berfungsi untuk mempelajari hasil realisasi produktivitas, sumber daya dan metode yang nantinya akan dijadikan bahan pertimbangan untuk perencanaan penjadwalan ke depan, sedangkan evaluasi yang dilakukan pada sistem manajemen proyek konvensional menggunakan media rapat mingguan dengan pembahasan progress realisasi, metode, sumber daya dan issue yang diharuskan untuk dirapatkan.

Hal di atas menunjukkan bahwa pada tahapanan planning sistem LPS lebih menonjolkan kolaboratif antar tim dalam pembuatan dan kontrol penjadwalan. Penjadwalan LPS selalu terupdate secara rutin atau dapat dikatakan sustainable updating schedule. Hal tersebut dikarenakan pada LPS terdapat beberapa tahapan yang digunakan untuk mengontrol pekerjaan dan adanya tahapan tersebut, menjadikan LPS terlihat lebih terstruktur. Sedangkan sistem manajemen konvensional lebih menitik beratkan pada PM dalam penetapan jadwal yang dibuat oleh tim penjadwalan. Penjawalan pada manajemen konvensional dibuat diawal, adapun pembuatan pada saat proyek berlangsung bersifat tidak rutin, bergantung pada progress pengerjaan dan kemunculan issue besar yang dapat mempengaruhi penjadwalan.
Dalam tahap konstruksi LPS mengacu pada produktivitas hasil kerja sedangkan sistem konvensional lebih mengacu kepada ketepatan waktu realisasi kerja. Kedua sistem manajemen proyek sama-sama mempunyai TBM, namun pada LPS sebelum melaksanakan TBM ada tahapan daily huddle yang berfokus kepada tim, PIC, mandor dan supplier. Issue yang muncul pada LPS dapat ditangani oleh reliable promise log sebagai issue controlling, sedangkan manajemen proyek konvensional lebih mengunggulkan keputusan PM dan hasil rapat atau berita acara. Laporan progress antara kedua sistem manajemen proyek secara garis besar sama, namun pada LPS terdapat progress realisasi harian sebagai control produktivitas kerja harian dan tambahan informasi untuk update schedule pada tahapan performance evaluation. Tahapan evaluasi antara kedua sistem manajemen proyek sama, hal yang berbeda adalah pada LPS diberi tambahan membahas realisasi produktivitas kerja untuk perencanaan penjadwalan ke depan.

\section{Data Fungsi CPM (Network Planning) - Bar Chart Pada Tahapan LPS}

Data yang diperoleh untuk mencari letak atau posisi dan fungsi CPM dan Bar Chart pada tahapan di LPS disajikan dalam bentuk tabel. Data tersebut dikelompokan sesuai konsep plan plan-do-check-act pada Tabel 3. 
Tabel 3. Data letak atau posisi dan fungsi CPM (network planning) dan Bar Chart pada tahapan di LPS

\begin{tabular}{|c|c|c|c|c|c|}
\hline NO & $\begin{array}{l}\text { PDAC } \\
(\text { Plan- } \\
\text { Do- } \\
\text { Check- } \\
\text { Act })\end{array}$ & Tahapan LPS & $\begin{array}{r}\text { Let: } \\
(n \\
\text { plant } \\
\text { Bar C } \\
\text { taha }\end{array}$ & $\begin{array}{l}\text { CPM } \\
\text { york } \\
\text { g) dan } \\
\text { rt pada } \\
\text { n LPS }\end{array}$ & $\begin{array}{c}\text { Keterangan Fungsi CPM (nerwork planning) dan Bar Chart } \\
\text { pada tahapan LPS }\end{array}$ \\
\hline \multirow[t]{8}{*}{1} & \multirow[t]{8}{*}{$\begin{array}{l}\text { Tahap } \\
\text { Plan }\end{array}$} & \multirow{2}{*}{$\begin{array}{l}\text { Master Schedule } \\
\text { Jadwal durasi waktu tiap pekerjaan } \\
\text { dari awal hingga akhir } \\
\text { pembangunan proyek. }\end{array}$} & CPM & Ada & $\begin{array}{l}\text { Menjadi penghubung antara milestone, item pekerjaan, dan urutan } \\
\text { pekerjaan. }\end{array}$ \\
\hline & & & $\begin{array}{l}\text { Bar } \\
\text { Chart }\end{array}$ & Ada & $\begin{array}{l}\text { Berfungsi untuk menampilkan durasi waktu seluruh item pekerjaan } \\
\text { secara visual dalam bentuk bagan balok }\end{array}$ \\
\hline & & \multirow{2}{*}{$\begin{array}{l}\text { Look a Head Schedule } \\
\text { Perencanaan waktu kerja selama } 6 \\
\text { minggu (six week scheduling) }\end{array}$} & CPM & Ada & $\begin{array}{l}\text { - Hubungan antar item pekerjaan pada six week scheduling. } \\
\text { - Durasi waktu tiap item pekerjaan pada six week scheduling. }\end{array}$ \\
\hline & & & $\begin{array}{l}\text { Bar } \\
\text { Chart }\end{array}$ & Ada & $\begin{array}{l}\text { - Berfungsi untuk menampilkan durasi waktu untuk pada six week } \\
\text { scheduling dalam bentuk bagan balok, satuan durasi mingguan. } \\
\text { Digunakan untuk mentransfer waktu mingguan yang diperoleh pada } \\
\text { phase scheduling kedalam look a head log dan merubahnya dalam } \\
\text { bentuk harian. Dalam penggambarannya, akan diberi keterangan } \\
\text { inisal waktu pengerjaan (siang, malam, siang-malam). }\end{array}$ \\
\hline & & \multirow{2}{*}{$\begin{array}{l}\text { Weekly Work Planning } \\
\text { Seleksi Hasil jadwal pekerjaan } \\
\text { mingguan dengan constraint } \\
\text { analysis (Analisa hambatan) dan } \\
\text { Shielding production (Analisa } \\
\text { kesiapan realisasi pekerjaan) }\end{array}$} & CPM & $\begin{array}{l}\text { Tidak } \\
\text { Ada }\end{array}$ & $\begin{array}{l}\text { Bentuk CPM tidak ditemukan dalam tahapan ini, hal tersebut } \\
\text { dikarenakan tahapan weekly work planning merupakan tahapan } \\
\text { pemilahan atau sortir pekerjaan yang siap dilakukan dan yang belum } \\
\text { siap. }\end{array}$ \\
\hline & & & $\begin{array}{l}\text { Bar } \\
\text { Chart }\end{array}$ & Ada & $\begin{array}{l}\text { Item pekerjaan pada Bar Chart look a head log akan diseleksi dengan } \\
\text { shielding production dan constraint log (untuk kesiapan realisasi). Item } \\
\text { pekerjaan yang lolos dipergunakan dalam penyusunan rencana workable } \\
\text { backlog (Bar Chart rencana pengerjaan harian) }\end{array}$ \\
\hline & & \multirow{2}{*}{$\begin{array}{l}\text { Daily Work Planning } \\
\text { Pada tahapan daily work planning, } \\
\text { dengan mengadakan } \\
\text { pertemuan/rapat tiap pagi sebelum } \\
\text { melaksanakan kegiatan (daily }\end{array}$} & CPM & $\begin{array}{l}\text { Tidak } \\
\text { Ada }\end{array}$ & \multirow{2}{*}{$\begin{array}{l}\text { Bentuk CPM dan Bar Chart tidak ditemukan pada tahapan DWP (Daily } \\
\text { Work Planning). Pada tahapan DWP hanaya berisikan rapat daily pre- } \\
\text { construction yang berisikan mengingatkan tentang metode kerja, waktu } \\
\text { pelaksanaan, kesiapan sumberdaya dan target yang harus diselesaikan } \\
\text { pada hari tersebut kepada seluruh pekerja, melalu daily huddle dan }\end{array}$} \\
\hline & & & $\begin{array}{l}\text { Bar } \\
\text { Chart }\end{array}$ & $\begin{array}{l}\text { Tidak } \\
\text { Ada }\end{array}$ & \\
\hline
\end{tabular}




\begin{tabular}{|c|c|c|c|c|c|}
\hline \multirow[t]{2}{*}{ NO } & \multirow[t]{2}{*}{$\begin{array}{l}\text { PDAC } \\
\text { (Plan- } \\
\text { Do- } \\
\text { Check- } \\
\text { Act }) \\
\end{array}$} & \multirow[t]{2}{*}{ Tahapan LPS } & \multicolumn{2}{|c|}{$\begin{array}{l}\text { Letak CPM } \\
\text { (nerwork } \\
\text { planning) dan } \\
\text { Bar Chart pada } \\
\text { tahapan LPS }\end{array}$} & \multirow[t]{2}{*}{$\begin{array}{l}\begin{array}{l}\text { Keterangan Fungsi CPM (nerwork planning) dan Bar Chart } \\
\text { pada tahapan LPS }\end{array} \\
\text { TBM (tools box meeting). }\end{array}$} \\
\hline & & & & & \\
\hline \multirow[t]{8}{*}{2} & \multirow[t]{8}{*}{$\begin{array}{l}\text { Tahap } \\
\text { Do }\end{array}$} & \multirow{2}{*}{$\begin{array}{l}\text { Constraint Analysis log } \\
\text { Tabel sumber daya yang berisi } \\
\text { jenis pekerjaan, hambatan suatu } \\
\text { pekerjaan, tanggal mulai } \\
\text { pekerjaan, dan PIC (person in } \\
\text { charge) } \\
\end{array}$} & CPM & $\begin{array}{c}\text { Tidak } \\
\text { Ada }\end{array}$ & \multirow{2}{*}{$\begin{array}{l}\text { Bentuk CPM dan Bar Chart tidak ditemukan pada tahapan constraint } \\
\text { analysis. Tahapan ini berisikan check list kesiapan sumber daya, } \\
\text { kelengkapan gambar kerja, tangga mulai pengerjaan, jenis kontrak dan } \\
\text { kolom keterangan hambatan muncul. }\end{array}$} \\
\hline & & & $\begin{array}{l}\text { Bar } \\
\text { Chart }\end{array}$ & $\begin{array}{c}\text { Tidak } \\
\text { Ada }\end{array}$ & \\
\hline & & \multirow{2}{*}{$\begin{array}{l}\text { Shielding Production } \\
\text { memastikan atau menyeleksi } \\
\text { pekerjaan yang siap dilaksanakan } \\
\text { dari segi waktu, lokasi dan sumber } \\
\text { daya }\end{array}$} & CPM & $\begin{array}{l}\text { Tidak } \\
\text { Ada }\end{array}$ & \multirow{2}{*}{$\begin{array}{l}\text { Bentuk CPM dan Bar Chart tidak ditemukan pada tahapan shielding } \\
\text { production. Tahapan ini berisikan check list pekerjaan yang siap } \\
\text { dikerjakan/ pekerjaan yang ready pada tahapan constraint analysis dan } \\
\text { look a head. }\end{array}$} \\
\hline & & & $\begin{array}{l}\text { Bar } \\
\text { Chart }\end{array}$ & $\begin{array}{c}\text { Tidak } \\
\text { Ada }\end{array}$ & \\
\hline & & \multirow{2}{*}{$\begin{array}{l}\text { Balancing \& Firs Run Studies } \\
\text { - Balancing. } \\
\text { Pemastian atau matching antara } \\
\text { gudang dengan tingkaat } \\
\text { produktivitas pekerjaan } \\
\text { - First run studies. } \\
\text { Berkolaborasi untuk } \\
\text { menganalisi pekerjaan, } \\
\text { penjadwalan dan sumber daya } \\
\text { untuk membuat metode kerja }\end{array}$} & CPM & Ada & $\begin{array}{l}\text { Berguna untuk menginformasikan hubungan pakerjaan. Pengelolaan } \\
\text { penyimpanan sumberdaya tahapan balancing dan pembuatan metode } \\
\text { kerja pada first run studies. }\end{array}$ \\
\hline & & & $\begin{array}{l}\text { Bar } \\
\text { Chart }\end{array}$ & $\begin{array}{l}\text { Tidak } \\
\text { Ada }\end{array}$ & $\begin{array}{l}\text { Bentuk Bar Chart tidak ditemukan pada tahapan ini. Balancing dan } \\
\text { First run studies, hanya menggunakan CPM untuk melihat hubungan } \\
\text { antar pekerjaan serta look ahead log dan constrant alnalysis untuk } \\
\text { memenejemen gudang dan pembuatan metode kerja. }\end{array}$ \\
\hline & & \multirow{2}{*}{$\begin{array}{l}\text { Workable Back } \text { Log } \\
\text { Daftar pekerjaan yang siap } \\
\text { dilakukan atau pekerjaan yang }\end{array}$} & CPM & Ada & $\begin{array}{l}\text { Berguna untuk mengatur ulang penjadwalan harian ketika terjadi } \\
\text { keterlambatan, perubahan volume dan design pada workable backlog. }\end{array}$ \\
\hline & & & Bar & Tidak & Dalam tahapan ini, bentuk Bar Chart tidak ditemukan. Dalam tahapan \\
\hline
\end{tabular}




\begin{tabular}{|c|c|c|c|c|c|}
\hline \multirow[t]{2}{*}{ NO } & \multirow[t]{2}{*}{$\begin{array}{l}\text { PDAC } \\
\text { (Plan- } \\
\text { Do- } \\
\text { Check- } \\
\text { Act }) \\
\end{array}$} & Tahapan LPS & \multicolumn{2}{|c|}{$\begin{array}{c}\text { Letak CPM } \\
\text { (nerwork } \\
\text { planning) dan } \\
\text { Bar Chart pada } \\
\text { tahapan LPS } \\
\end{array}$} & \multirow{2}{*}{$\begin{array}{l}\text { Keterangan Fungsi CPM (nerwork planning) dan Bar Chart } \\
\text { pada tahapan LPS } \\
\qquad \begin{array}{l}\text { ini lebih berfokus kepada pengaturan ulang jadwal pekerjaan yang lolos } \\
\text { seleksi shielding production dengan menggunakan CPM. }\end{array}\end{array}$} \\
\hline & & $\begin{array}{l}\text { lolos dari seleksi shielding } \\
\text { production }\end{array}$ & Chart & Ada & \\
\hline \multirow[t]{2}{*}{3} & \multirow[t]{2}{*}{$\begin{array}{l}\text { Tahap } \\
\text { Check }\end{array}$} & \multirow{2}{*}{$\begin{array}{l}\text { PPC (Percent Plan Completed) } \\
\text { Prosentase realisasi lapangan atau } \\
\text { progress lapangan }\end{array}$} & CPM & $\begin{array}{l}\text { Tidak } \\
\text { Ada }\end{array}$ & $\begin{array}{l}\text { CPM tidak ditemukan dalam tahapan ini, karena tahapan ini hanya } \\
\text { berisikan prosentase realisasi kerja, baik bulanan, mingguan atau harian. }\end{array}$ \\
\hline & & & $\begin{array}{l}\text { Bar } \\
\text { Chart }\end{array}$ & Ada & $\begin{array}{l}\text { Bentuk Bar Chart tidak ada namun hasil dari PPC mingguan pada LPS } \\
\text { berguna unntuk mengisi schedule pada Bar Chart master schedule }\end{array}$ \\
\hline \multirow[t]{4}{*}{4} & \multirow[t]{4}{*}{$\begin{array}{l}\text { Tahap } \\
\text { Act }\end{array}$} & \multirow{2}{*}{$\begin{array}{l}\text { Reliable Promise (issue log) } \\
\text { Tabel issue, berisikan tanggal } \\
\text { kemunculan issue, issue, PIC } \\
\text { (person in charge) dan tanggal } \\
\text { penyelesaian, status issue hari ini } \\
\text { (update stat hariaan) }\end{array}$} & CPM & Ada & $\begin{array}{l}\text { Dengan menggunakan CPM, Issue yang muncul pada tahapan reliable } \\
\text { promise akan diselesaikan dengan cara mengatur ulang waktu } \\
\text { pelaksanaan. Hasil pengaturan issue dicantumkan pada Workable back } \\
\text { log }\end{array}$ \\
\hline & & & $\begin{array}{l}\text { Bar } \\
\text { Chart }\end{array}$ & $\begin{array}{l}\text { Tidak } \\
\text { Ada }\end{array}$ & $\begin{array}{l}\text { Pada tahap ini peranan Bar Chart tidak ditemukan, pada tahap reliable } \\
\text { promise, hanya berisikan isu yang muncul dan penangguang jawab atau } \\
\text { PIC menggunakan CPM untuk mengatur ulang waktu pelaksanaan } \\
\text { pekerjaan yang bermasalah. }\end{array}$ \\
\hline & & \multirow{2}{*}{$\begin{array}{l}\text { Performance Evaluation } \\
\text { Tahapan evaluasi pekerjaan yang } \\
\text { sudah terlaksana (mingguan) }\end{array}$} & CPM & $\begin{array}{l}\text { Tidak } \\
\text { Ada }\end{array}$ & \multirow{2}{*}{$\begin{array}{l}\text { Performance evaluation merupakan tahapan evaluasi, kolaboratif tim } \\
\text { untuk melihat produktivitas pekerjaan yang sudah terealisasi untuk } \\
\text { merencanakan pekerjaan di minggu berikutnya menjadi unggulan pada } \\
\text { tahapan ini. }\end{array}$} \\
\hline & & & $\begin{array}{l}\text { Bar } \\
\text { Chart }\end{array}$ & $\begin{array}{l}\text { Tidak } \\
\text { Ada }\end{array}$ & \\
\hline
\end{tabular}


Hasil Akhir Analisa Fungsi CPM (Network Planning) - Bar Chart Pada Tahapan LPS dengan penelitian yang sudah ada.

Hasil akhir analisa letak atau posisi dan fungsi CPM (network planning) dan Bar Chart pada tahapan di LPS pada fase Plan, CPM muncul pada tahapan master scheduling dan look a head scheduling, sedangkan Bar Chart muncul pada tahapan master scheduling, look a head scheduling dan weekly work planning. Peranan CPM pada tahapan master scheduling menjadi penghubung antara milestone, item pekerjaan, dan urutan pekerjaan. Sedangkan Bar chart berfungsi untuk menampilkan durasi waktu seluruh item pekerjaan secara visual dalam bentuk bagan balok pada tahapan tersebut. Pada tahap look a head.

Pada tahapan look a head scheduling, CPM berperan untuk mencari hubungan antar item pekerjaan serta menetapkan durasi waktu tiap item pekerjaan pada six week scheduling, Sedangkan Bar Chart berfungsi untuk menampilkan durasi waktu pada six week scheduling dalam bentuk bagan balok dan digunakan untuk mentransfer waktu mingguan yang diperoleh pada phase scheduling kedalam look a head log dan merubahnya dalam bentuk harian. Dalam penggambarannya, akan diberi keterangan inisal waktu pengerjaan (siang, malam, siang-malam). Hasil ini sejalan dengan salah satu ashil penelitian Hamzeh, et al (2014), Lookahead Planning yang sukses bergantung pada antisipasi tugas dengan memecah tugas ke tingkat operasi, merancang operasi tersebut, dan membuat tugas ready dengan mengidentifikasi dan menghilangkan kendala pada tugas sehingga tugas dapat menjadi tugas yang dapat dieksekusi.

Peranan Bar Chart pada weekly work planning berguna sebagai penyeleksi item pekerjaan atau item pekerjaan pada Bar Chart di look a head log akan diseleksi dengan shielding production dan constraint log (untuk kesiapan realisasi). Item pekerjaan yang lolos dipergunakan dalam penyusunan rencana workable backlog (Bar Chart rencana pengerjaan harian). Hasil tersebut sejalan dengan penelitian Heery, (2010) yaitu pada tahapan Work Week Planning (WWP) memungkinkan seleksi kesiapan pekerjaan secara berkelanjutan.

Pada fase $D O$, bentuk dan fungsi yang terlihat adalah dari CPM, pada tahapan balancing, first run studies dan workable back log. Pada tahap balancing dan firs run studies, CPM Berguna untuk menginformasikan hubungan pakerjaan. Pengelolaan penyimpanan sumberdaya tahapan balancing dan pembuatan metode kerja pada first run studies. Sedangkan pada tahap workable back log, CPM berguna untuk mengatur ulang penjadwalan harian ketika terjadi keterlambatan, perubahan volume dan design. Hasil ini dapat diperkuat dengan hasil penelitian Husen, (2011) yaitu, pada metode CPM dapat dilihat hubungan antar pekerjaan serta lintasan kritis. Disisi lain dalam metode ini dapat dilihat waktu penyelesaian kegiatan yang dapat 
ditunda atau yang harus segera diselesaikan.

Fase check, Bentuk Bar Chart tidak atau tidak ditemukan, namun hasil dari PPC mingguan pada LPS berguna unntuk mengisi schedule pada Bar Chart master schedule atau mengisi prosentase realisasi pekerjaan. Pada fase act, CPM berguna untuk mengatur waktu penyelesaian issue. Adapun issue yang muncul pada tahapan reliable promise akan diselesaikan dengan cara mengatur ulang waktu pelaksanaan. Hasil pengaturan issue dicantumkan pada tahapan Workable backlog.

\section{SIMPULAN}

Simpulan yang diperoleh dari penelitian ini adalah bahwa dari hasil analisa perbedaan sistem manajemen proyek konvensional (Network planning (CPM - Bar Chart) dengan Last Planner System menunjukan bahwa LPS lebih mengunggulkan kolaboratif tim, production control system, perealisasian janji dan penjadwalan schedule secara sustainable. Sedangkan sistem konvensional lebih mengacu atau mengandalkan dari pada keputusan PM, rapat mingguan, target progress rencana dan berita acara. Pada tahapan konstruksi perbedaan terletak pada penggunaan daily huddle dan Tools Box Meeting (TBM) pada LPS sedangkan sistem konvensional hanya menggunakan TBM saja.

Fungsi dan posisi CPM (network planning) dalam LPS dapat ditemukan pada: Master Scheduling dan Look a head schedule (fase plan), Balancing dan first run studies (fase do), Workable back log (fase do), dan
Reliable promise/ issue log (fase act). Sedangkan fungsi dan posisi Bar Chart dalam LPS dapat ditemukan pada Master Scheduling, Look a head schedule dan Weekly work planning (fase plan), serta Percent Plan Completed (fase check).

\section{DAFTAR PUSTAKA}

Ariyanto, A., 2010, Eksplorasi Metode Bar Chart, CPM, PDM, Pert, Line Of Balance Dan Time Chainage Diagram Dalam Penjadwalan Proyek Konstruksi. Pasca Sarjana Teknik Sipil. Universitas Diponegoro

Ballard, H. G., 2000, The Last Planner System of Production Control. Journal of Chemical Information and Modeling, 53 (9), 1689-1699. https: //doi.org/10.1017/

CBO9781107415324.004

Ballard, H. G., Tommelein, I., Hamzeh, F., 2007, The Last Planner Production WorkbookImproving Reliability in Planning and Workflow. Lean Construction Institute

Direktorat Riset dan Pengabdian Masyarakat Universitas Indonesia, 2007, Kajian Aspek Kemasyarakatan DI Dalam Pengembangan Infrastruktur Indonesia, Universitas Indonesia Febri, Triwibowo, Imron, Wijaya, R., 2013, Perbandingan metode Penjadwalan pada Proyek Konstruksi yang bersifat lilier (Studi kasus menggunakan metode Bar Chart, Network Planning dan Time Chainage 
Diagram). Undergraduate thesis, Diponegoro University

Fernandez-Solis, J. L., Porwal, V., Lavy, S., Shafaat, A., Rybkowski, Z. K., Son, K., Lagoo, N., 2013, Survey of Motivations, Benefits, and Implementation Challenges of Last Planner System Users. Journal of Construction Engineering and Management, 139(4), 354-360

Hamzeh, R. F., Saab, I., Iris, D., Tommelein \& Ballard H. G., 2014, Understanding the role of "task anticipated" in look a head planning though simpulation. Automation in construction. Science Direct

Heery, 2015, An Introduction Do Pull Planning. IFMA

Human, A. D., \& Zuldi, S., 2018, Penilaian Kesiapan Praktisi Indonesia Terhadap Last Planner System. Teknik Sipil. Universitas Diponegoro

Husen, A., 2011, Manajemen Proyek, Penerbit Andi, Yogyakarta

Mudzakir, C. A., Setiawan, A., Wibowo, A. M., Khasani, R. R., 2017, Evaluasi Waste Dan Implementasi Lean Construction (Studi Kasus: Proyek Pembangunan Gedung
Serbaguna Taruna Politeknik Ilmu Pelayaran Semarang). Jurnal Karya Teknik Sipil, Volume 6, Nomor 2, Tahun 2017, Halaman $145-158$ Online di: http://ejournals1.undip.ac.id/index.php/jkts

Pellicer, E., Cerveró, F., Lozano, A., Ponz-Tienda, L. J., 2015, THE Last Planner System Of Construction Planning And Control As A Teaching And Learning Tool. Research Gate

Ramadhani, R. I., 2017, Koordinasi Dalam Pembangunan Infrastruktur Dan Pengembangan Sumber daya Manusia Oleh PT Swakarsa Sinar Sentosa Di Desa Muara Wahau Kecamatan Muara Wahau Kabupaten Kutai Timur. eJournal Pemerintahan Integratif, 2017, 5 (1): 148-158

Siswanto, S., Suyanto, 2017, Metodologi Penelitian Kombinasi KualitatifKuantitatif Kedokteran dan Kesehatan. BOSSSCRIPT Klaten Selatan

PT. Wijaya Karya Tbk., 2015, Proyek Rehabilitasi Saluran induk dan Seukunder Kelambu Kiri, BKKi.1-BKKi.15. Demak, Jawa Tengah 